\title{
Agricultural change in Copper Age Croatia (ca. 4500-2500 cal B.C)?
}

\author{
Kelly Reed ${ }^{1}$
}

Received: 3 August 2015 / Accepted: 9 March 2016 / Published online: 2 April 2016

(C) The Author(s) 2016. This article is published with open access at Springerlink.com

\begin{abstract}
The Copper Age in the Carpathian Basin is marked by a distinct change in settlement patterns, material culture, social traditions and subsistence practices; however, few studies address the nature of crop cultivation in the region. This paper examines new archaeobotanical data from 13 Copper Age (ca. 4500-2500 cal BC) sites located in continental Croatia, in order to assess the extent to which crop agriculture may have changed and contributed to overall subsistence economies in the Copper Age. From the archaeobotanical results, a dominance in einkorn and emmer is seen followed by barley. Less frequently millet, naked wheat and spelt/new glume wheat are also recovered, but due to their limited numbers, it is less clear whether they were grown as crops or represent weeds. Pulses (e.g. lentil, pea and grass pea), fruit remains (e.g. cornelian cherry and chinese lantern) and wild plant and weed species are also recovered, although more commonly from the late Copper Age sites. The archaeobotanical results show a clear reduction in the quantity and range of plant species recovered during the early/middle Copper Age; however, this is likely the result of taphonomic bias rather than a reduction in crop cultivation. The results therefore highlight problems of recovery bias in the region, which makes comparisons between sites as well as the reconstruction of crop husbandry regimes difficult. Overall, the results from continental Croatia suggest that the type of crops
\end{abstract}

Electronic supplementary material The online version of this article (doi:10.1007/s12520-016-0330-3) contains supplementary material, which is available to authorized users.

Kelly Reed

kellyreed@hotmail.co.uk

1 School of Life Sciences, University of Warwick, Coventry CV4 7AL, UK cultivated continued relatively unchanged from the late Neolithic, although it is clear that more research is desperately needed to explore the relationship between crop agriculture and the changing socio-economic environment of the Copper Age in the region.

Keywords Archaeobotany $\cdot$ Eneolithic $\cdot$ Agro-pastoralism · Crop cultivation · Carpathian Basin

\section{Introduction}

The Copper Age in the Carpathian Basin is marked by a distinct change in settlement patterns, material culture, social traditions and subsistence practices (Bánffy 1994; BognarKutzian 1972:160-164; Gyucha et al. 2014; Kalicz 1970; Parkinson 2006). However, limited systematic investigations have led to an inadequate understanding of crop agriculture and its role in society from ca. 4500 to $2500 \mathrm{cal} \mathrm{BC}$. This is particularly evident in Croatia where almost no information exists on the development of agriculture during the Copper Age. This paper therefore presents new archaeobotanical evidence from 13 Copper Age sites in continental Croatia, exploring the range of domestic crops that may have been cultivated at this time. In addition, the data will be examined in light of prevailing theories on the development of Copper Age subsistence strategies and assess the extent to which agriculture may have changed and contributed to overall subsistence economies in the region.

The 13 Copper Age study sites include Barbarsko, Čeminac-Vakanjac, Čepinski Martinci-Dubrava, ĐakovoFranjevac, Jurjevac-Stara Vodenica, Lasinja, Potočani, Pajtenica-Velike Livade, Slavča, Tomašanci-Palača, Virovitica-Batelije, Vinkovci, 14 Matije Gupca and Vučedol (Fig. 1). Located within continental Croatia, the 
Fig. 1 Location of Croatian study sites. 1 Lasinja, 2 Barbarsko, 3 Potočani, 4 Virovitica-Batelije, 5 Slavća, 6 Čeminac-Vakanjac, 7 Čepinski Martinci-Dubrava, 8 PajtenicaVelike Livade, 9 Jurjevac-Stara Vodenica, 10 Tomašanci-Palača, 11 Đakovo-Franjevac, 12

Vinkovci, 14 Matije Gupca, 13 Vučedol

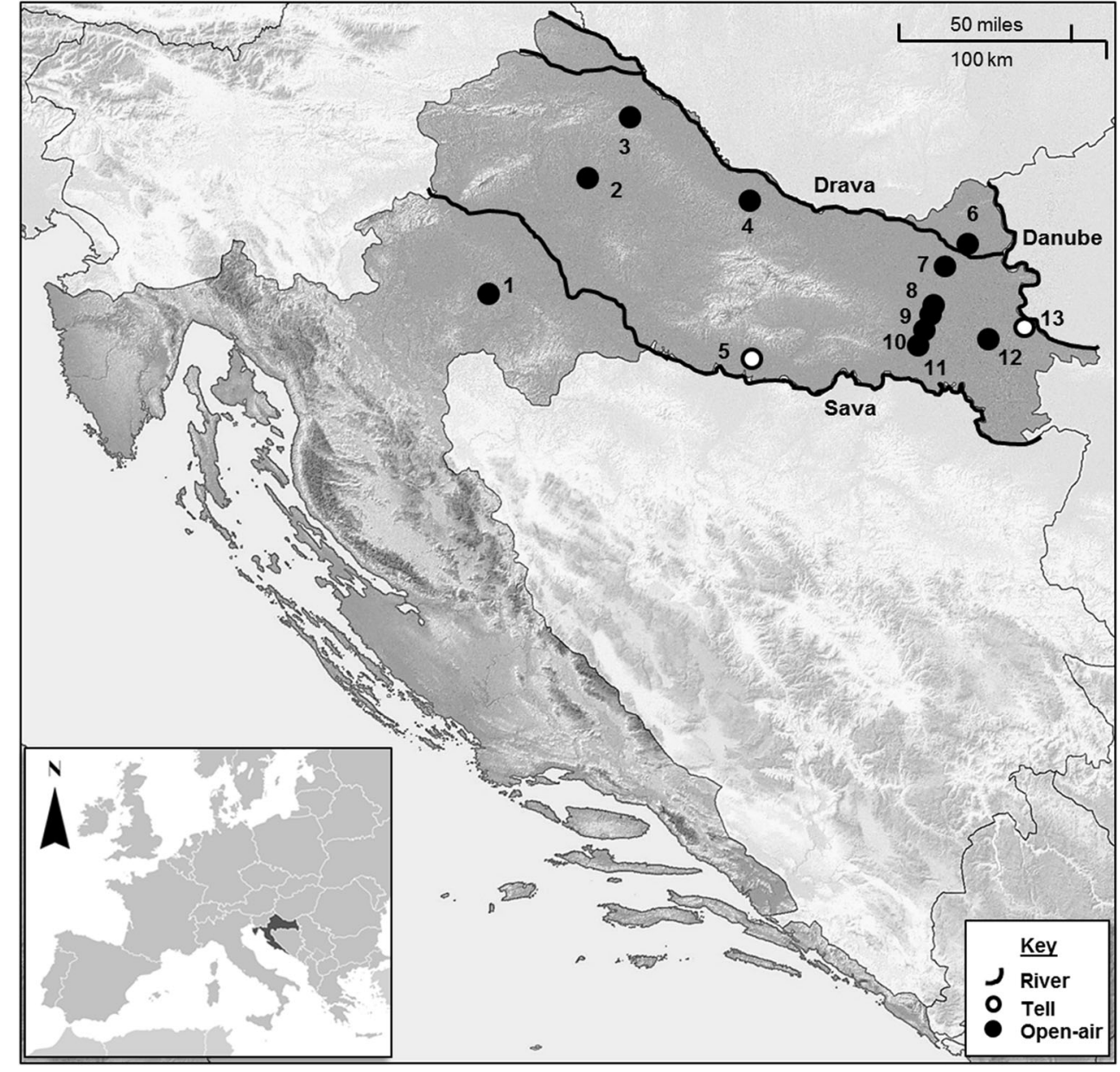

region is roughly bordered by the river Drava to the north, the Sava to the south and the Danube to the east and is characterised by relatively flat and extremely fertile loess plains. Continental Croatia is also situated within the south-western area of the Carpathian Basin, which is bordered by the Carpathian Mountains, the Alps, the Dinaric Alps and the Balkan Mountains, and also includes present day Hungary, eastern Slovenia, northern Serbia, western Slovakia, northern Bosnia and Herzegovina and northwestern Romania (Fig. 2). The area covers ca. 300, $000 \mathrm{~km}^{2}$ and consists of two main geographical units, the peripheral mountains and the central fertile alluvial plains, i.e. Pannonian Plain, which is roughly dissected by the Danube and Tisza rivers.

\section{Defining the Copper Age in the Carpathian Basin}

The transition from the Neolithic to the Copper Age, or Eneolithic, was not immediate and so many different interpretations exist as to the exact start date of the Copper Age (Sraka 2014). Historically, the Copper Age was marked by the start of copper metallurgy; however, the emergence of copper mining and metallurgy is nowadays unquestionably connected to the Vinča culture, with the production of copper tools and weapons of basic appearance emerging in the central Balkans ca. 5000 to $4500 \mathrm{BC}$ during the late Neolithic (Antonović 2009; Šljivar 2006; Radivojević et al. 2010). The Copper Age is therefore defined by the changes seen in settlement patterns, ceramics, burial customs and trade networks, which occurred across the Carpathian Basin from ca. 4500 to 2500 cal BC (Bánffy 1994; Bognar-Kutzian 1972:160164; Gyucha et al. 2014; Kalicz 1970; Parkinson 2006). However, defining cultural boundaries and chronologies can be problematic (Raczky and Siklósi 2013; Sraka 2014). In Croatia, the relationships between the various Copper Age cultures are uncertain, so this paper will not focus on or try to disentangle the complexities of the cultural traditions present in this region. That being said, Fig. 3 outlines the suggested development of cultures within continental Croatia with an arbitrary timespan of early/middle Copper Age (ca. 4500 to $3500 \mathrm{cal} \mathrm{BC)}$ and late Copper Age (ca. 3500 to 2500 cal BC) that will be used to examine the archaeobotanical data. 
Fig. 2 Map of the Carpathian Basin showing the location of Copper Age settlements with archaeobotanical remains dicussed in the text. See Table S1 for a detailed list of the sites

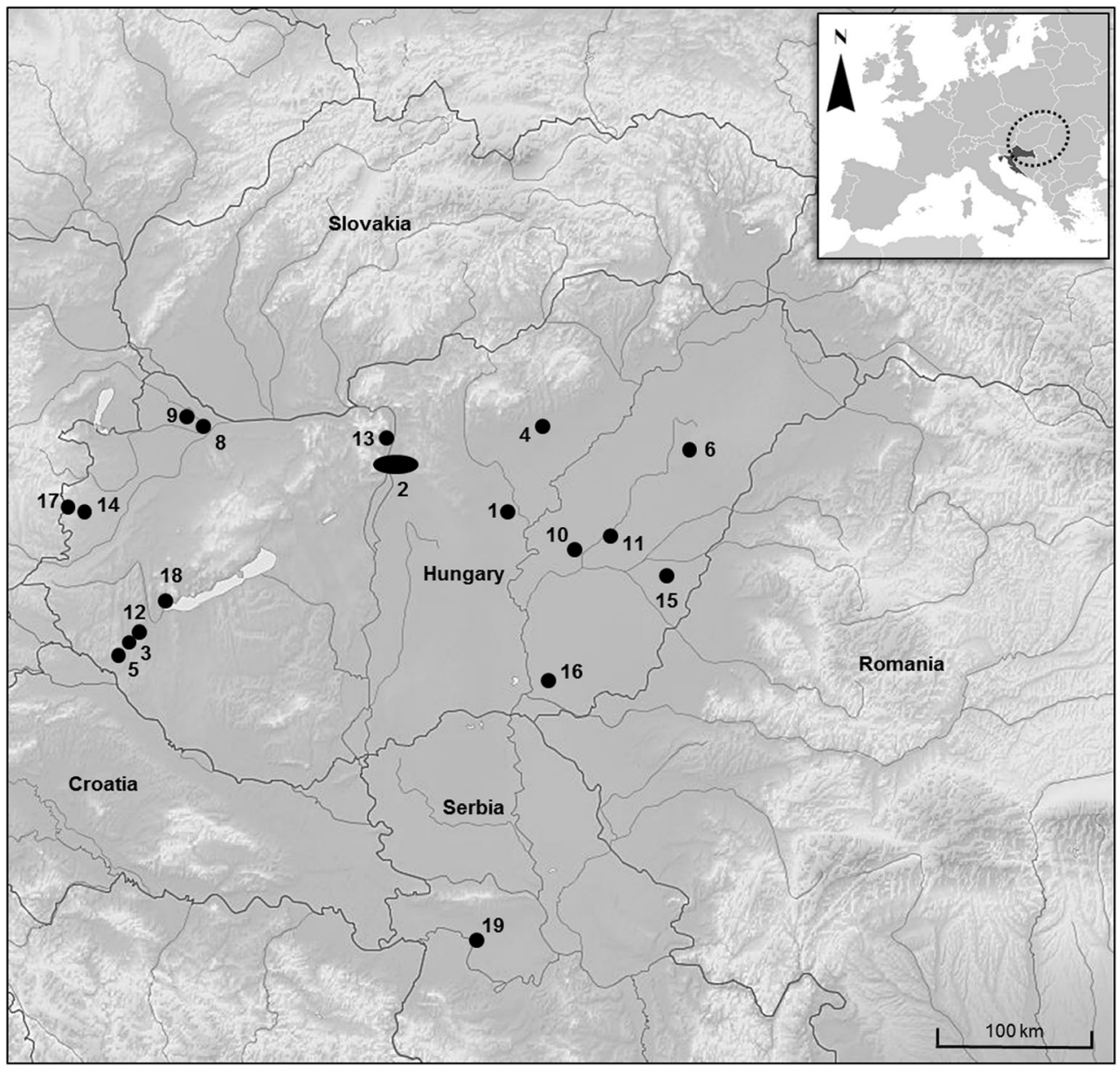

\section{The Archaeological evidence}

The archaeological evidence for the Copper Age in the Carpathian Basin is sporadic, with much of the period being characterised by generalised patterns. The majority of the evidence comes from the region of modern day Hungary, although zooarchaeological and archaeobotanical evidence is still fairly limited and almost non-existent in Croatia and Serbia. Typically, the transition to the Copper Age has been seen as a period where the large multilayer tell sites of the late Neolithic were gradually replaced by smaller dispersed and more transient settlements and a shift in subsistence practices that focused more on animal husbandry than crop agriculture (Bognar-Kutzian 1972; Bökönyi 1974; Gyulai 2010; Parkinson 2006:186). In Hungary, Parkinson (2006:144145) showed a $700 \%$ increase in sites during the Neolithic/ Copper Age transition, suggesting that the pattern of residential mobility expanded considerably. His research showed two distinct settlement patterns: (a) the foundation of new site clusters in previously uninhabited micro-regions located in a particular river drainage and (b) the expansion of sites over a larger area within a previously inhabited late Neolithic cluster (Parkinson 2006:144). Evidence suggests that the small early
Copper Age settlements began to function as economically integrated units, with different households specialising in different craft activities (Parkinson et al. 2004). In addition, settlement specialisation is seen in eastern Serbia where a number of early Copper Age sites show a greater focus on copper ore extraction, while others show a continued focus on animal husbandry (Kapuran and Milošević 2013). Large long-lived formal cemeteries also appear at this time, along

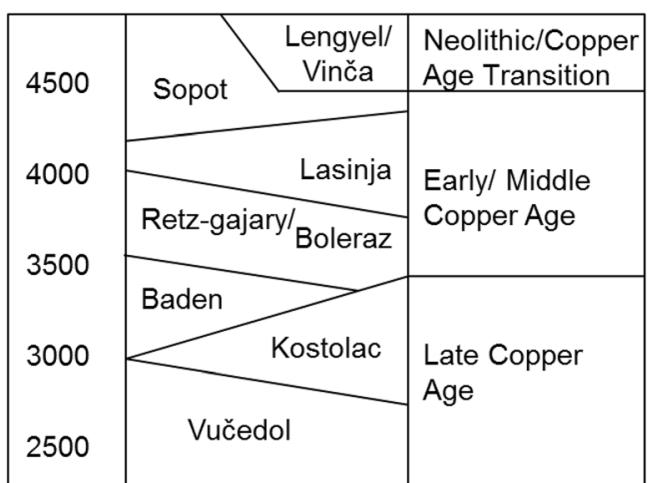

Fig. 3 Chronological depiction of archaeological cultures in continental Croatia during the Copper Age 
with an increase in grave goods, but they are usually isolated and unassociated with settlement sites (Bognar-Kutzian 1963, 1972; Chapman 2000).

By the late Copper Age, settlement patterns once again begin to change with the development of large tell sites, similar to the late Neolithic (Tasić 2003-2004). In Croatia, it is suggested that larger tell settlements may have represented a socioeconomic centre with potential strategic, hierarchical and communication roles, with smaller satellite sites clustered typically near rivers or streams (Balen 2002, 2011; Durman 1995; Forenbaher 1994). In Hungary, Baden culture sites show a dense network of large and small sites, including caves, occupied for long and short periods, ranging over upland and lowland locations (Horváth and Virág 2003:127). The development of local metallurgical centres and the unequal growth of wealth may also explain the increase of fortified tell sites in the Carpathian, along with the expansion of long distance regional exchanges (Jovanović 2009; Sherratt 1998:10; Šljivar 2006). The nature of Copper Age societies is therefore likely to have varied regionally, depending on local geography, accessibility to resources and socio-economic inclinations. For example, the strong metallurgical base of the late Copper Age Vučedol culture, seen in the arc of mines along the mountains of the Carpathian Basin, would have resulted in faster technological innovations and social change closer to these centres, while those further afield would have developed at a slower rate, potentially holding on longer to late Neolithic values and traditions (Jovanović 1971).

\section{Evidence of animal husbandry practices}

Traditional theories marked the Copper Age as a period which saw the impact of the 'Secondary Products Revolution', where technological innovations and subsistence changes included the introduction of the light plough, the wheel, animal traction, wool and milk production, manifesting in the increase in cattle in zooarchaeological assemblages (Bognar-Kutzian 1972; Bökönyi 1974; Sherratt 1981, 1983). Linked with these changes was the widespread practice of grazing animals in open areas (incorporating the practice of transhumance), the establishment of specialised pastoral subsistence strategies, as well as greater population mobility and long-distance transportation of goods. It was suggested that the larger cattle herds would require more grazing land, which was why settlements became smaller and more dispersed at the beginning of the Copper Age (Bognar-Kutzian 1972; Bánffy 1994; Molnár and Sümegi 2007).

Today, the increase in cattle and the exploitation of secondary products is clearly seen during the Neolithic, where mixed husbandry regimes were practiced (Copley et al. 2003; Craig et al. 2003, 2005; Evershed et al. 2008; Greenfield and Arnold 2015; Orton 2012; Spangenberg et al. 2006). Instead, the early Copper Age faunal remains, although particularly limited, have begun to reveal variations in the proportion of domestic species at sites. For example, a reduction in cattle and increase in pig is seen in certain areas of Hungary (Parkinson et al. 2004; Giblin 2009), while cattle still seem to dominate the few Croatian and Serbian sites excavated (Balen 2005; Miculinić and Mihaljević 2003; Radmanović et al. 2014; Trbojević-Vukičević et al. 2011; Tasić 1979). In addition, an increased focus on domesticates is seen from assemblages where there is a marked reduction in wild animals identified from the late Neolithic to the early Copper Age (Bartosiewicz 2005; Gyucha et al. 2013).

Continuation in herd management from the Late Neolithic is supported by stable isotope and lipid studies, which suggest that herding remained small-scale and that dairy use was minimal (Giblin 2009; Giblin et al. 2013, Hoekman-Sites and Giblin 2012). They proposed that the cultural changes that occurred at the beginning of the Copper Age were associated with the emergence of smaller independent farmsteads, as well as the possible use of secondary products like manure, rather than a dramatic increase in herds and the use of secondary products (ibid.). Similar herd mobility is also seen from a study on sheep/goat and cattle molars which indicated that the tested animals were not herded in upland areas in the Carpathian Mountains (Giblin 2014). This is supported by stable isotope research in Romania, which shows that late Copper Age domestic stocks were reared within close proximity of the settlements, rather than through large-scale seasonal mobility (Balesse et al. 2015). However, herd movement may be identified from cave sites along the Dinaric Alps, which show evidence of seasonal/periodic use from the Neolithic to the Bronze Age as herd pens and camps (Mlekuž 2007; Reed 2015). Animal husbandry strategies are therefore likely to have varied regionally depending on the local environment and settlement preferences.

Pastoral specialisation has also been linked to the development of broad exchange networks and markets, and an increase in social complexity and political centralisation (Sherratt 1981, 1983), while general herd based strategies provide for local consumption and subsistence security (Stein 1987). Evidence of plant and animal specialisation and market economies can be identified from the late Bronze Age, where 'palace-economies' geared towards surplus production, redistribution and trade develop in the eastern Mediterranean (e.g. Halstead 1992, 1995a; Sherratt and Sherratt 1993; Foxhall 1995; Rougemont 2014). However, for the Copper Age large-scale surplus production, beyond what may be classed as a 'normal' surplus and trade (Halstead 1987, 1989), is not evident in the archaeological record.

Strong symbolic and ceremonial values also seem to exist for certain domestic animals; for example, pig burials were discovered at the late Copper Age site of akovo-Franjevac, Croatia (Balen 2011:165). In addition, late Copper Age Baden culture cemeteries in the Carpathian Basin commonly contain 
animal burials, predominantly cattle, as well as fired clay cart models (Anthony 2007:159; Chapman 2000:312; Horváth 2010).

\section{Evidence of crop husbandry practices}

Evidence of Copper Age crop agriculture in the Carpathian Basin is relatively infrequent and less investigated than the Neolithic or Bronze Age. In eastern Slovenia, no archaeobotanical remains seem to be dated to the Copper Age, while in western Slovenia, only six sites have identified plant remains dating to this period (Culiberg et al. 1992; Jeraj et al. 2009; Šercelj and Culiberg 1980, 1984; Šercelj 19811982; Tolar et al. 2011; Velušček et al. 2004). Bosnia and Herzegovina too has no identified archaeobotanical material dating to the Copper Age. In northern Serbia, only one site, Gomolava (Van Zeist 2003), has so far yielded plant remains from late Copper Age levels, and in north-west Romania, only one late Copper Age/early Bronze Age site, Cheile Turzil, has archaeobotanical evidence (Ciută 2009). In Slovakia, archaeobotanical remains have been identified from 18 sites (Hajnalová 2007), while in Hungary, 28 sites have evidence of Copper Age plant remains (Gyulai 2010; Kasper 2003; Kenéz et al. 2014). In Croatia, two coastal sites have archaeobotanical evidence (Huntley 1996; Borojević et al. 2008), while in continental Croatia, only the preliminary results of three of the study sites published here, PajtenicaVelike Livade, Đakovo-Franjevac and Jurjevac-Stara Vodenica, provide any archaeobotanical evidence in the region (Đukić 2014; Reed 2011).

Generally, cereal remains are dominated by barley (Hordeum vulgare ssp. vulgare), both naked and hulled, einkorn (Triticum monococcum) and emmer (Triticum turgidum ssp. dicoccum - formerly Triticum dicoccum). Less common are the occasional finds of broomcorn millet (Panicum miliaceum), foxtail millet (Setaria italica), naked wheat (Triticum turgidum ssp. durum/Triticum aestivum), 'new type' glume wheat and spelt (Triticum aestivum ssp. spelta). Whether these latter species were cultivated as crops during the Copper Age is still debated. For example, spelt and broomcorn millet are not believed to have been cultivated as crops until sometime during the 3rd millennium BC (Akeret 2005; Jacomet 2008; Motuzaite-Matuzeviciute et al. 2013; Valamoti 2013).

Pulses are particularly rare during this period with only a few finds of pea (Pisum sativum), lentil (Lens culinaris), grass pea (Lathyrus sativus) and bitter vetch (Vicia ervilia). Evidence of flax (Linum usitatissimum) is also uncommon, except for the discovery of a Copper Age pot that contained over 3000 flax seeds at Lovice-Pod, Slovakia (Hajnalová 2007). Other oil plants recovered include a large deposit of poppy (Papaver somniferum), found at Hočevarica, Slovenia (Tolar et al. 2011), and the presence of charlock (Sinapis arvensis) at Öcsöd-Kendereshalom, Hungary, may also indicate oil extraction (Gyulai 2010:88). Common wild fruit and nut remains include cornelian cherry (Cornus mas), hazelnut (Corylus avellana), grape (Vitis vinifera ssp. sylvestris), chinese lantern (Physalis alkekengi), raspberry/blackberry (Rubus sp.) and acorns (Quercus sp.). A range of wild plant and weed species are also commonly identified including grasses (e.g. Bromus sp.) and fat hen (Chenopodium album).

Due to the largely restricted datasets available for this region, there is limited information about the types of crop husbandry regimes that may have been practiced (e.g. weeding, ploughing, manuring, irrigation). The use of animal traction, a key aspect of the 'Secondary Products Revolution', would have increased a household's productivity in areas such as field tillage, which can be up to 15 times faster than manual cultivation, and the transportation of goods (Sherratt 1981, 1983; Halstead 1995b; Bogucki 1993). Unlike northwest Europe, where plough marks have been seen since ca. 3500 cal BC (Prøsch-Danielsen 1993; Greenfield 2010), no plough marks or remains of the plough's themselves have been found in the Carpathian Basin. Zooarchaeological evidence of traction-related pathologies have tentatively shown an increase during the late 4th millennium BC suggesting a link with the spread of the plough and wheeled vehicles (Greenfield 2010). However, in the Carpathian Basin, evidence of plough cultivation from the archaeobotanical record has not been identified until the Bronze Age, inferred from the increase in open-ground herbaceous species, such as cornflower (Centaurea sp.), knotweeds (Polygonum sp.) and docks (Rumex sp.), as well as an increase in cereal pollen in Hungary (Gardner 2002; Gyulai 1993). On a theoretical level, Chapman (1981:92-4) proposed that ard cultivation may have developed at some of the large late Neolithic Vinča sites in order to utilise the fertile chernozem soils in the region, while Halstead (1995b) suggested that the penetration of Copper Age communities into 'marginal' environments indicated the adoption of the plough. However, given the evidence, so far, it is difficult to determine the extent to which communities may have employed plough cultivation during the Copper Age in the Carpathian Basin and further evidence is clearly needed.

\section{Methodology}

During 1999 to 2014, archaeobotanical samples were collected from 13 sites; Barbarsko, Čeminac-Vakanjac, Čepinski Martinci-Dubrava, Đakovo-Franjevac, Jurjevac-Stara Vodenica, Lasinja, Potočani, Pajtenica-Velike Livade, Slavća, Tomašanci-Palača, Virovitica-Batelije, Vinkovci, 14 Matije Gupca, and Vučedol (Fig. 1). Two types of site were excavated: flat, or horizontal, settlements, which have only a few layers of occupation, and tell sites, which have multiple episodes of rebuilding within a relatively concentrated area. The tell sites Slavća and Vučedol were sampled over a number 
of field seasons while the remaining flat settlements were sampled as part of rescue excavations commissioned by the Ministarstvo Kulture Republike Hrvatske (Croatian Ministry of Culture). In addition to the settlements, samples were also taken from Potočani, a large burial pit filled with 50 individuals.

Each sampling method was determined and implemented by the directors of the excavation in relation to their own aims and objectives. Samples from Barbarsko, Đakovo-Franjevac, Jurjevac-Stara Vodenica, Lasinja, Pajtenica-Velike Livade, Potočani, Tomašanci-Palača and Virovitica-Batelije were recovered only from pit features due to heavy erosion of the sites. The remaining sites were sampled from a range of contexts relating to human activities, such as settlement areas, house floors, hearths, pits and ditches. Sample sizes were not recorded for any of the samples, but an estimate has been calculated based on the directors sampling strategy. In general, a minimum of one bucket (ca. 11 l) of sediment was collected for each sample, although at Čepinski Martinci-Dubrava and Čeminac-Vakanjac, a minimum of two buckets were collected per sample.

Flotation was conducted either by bucket flotation or using a flotation machine with sieves ranging from $250 \mu \mathrm{m}$ to $1 \mathrm{~mm}$. Many of the sieve sizes are estimated, but it is believed that a 1 $\mathrm{mm}$ sieve was used for many of the rescue sites, Barbarsko, Đakovo-Franjevac, Jurjevac-Stara Vodenica, Lasinja, Pajtenica-Velike Livade, Potočani, Tomašanci-Palača, Vučedol and Virovitica-Batelije, $300 \mu \mathrm{m}$ at ČeminacVakanjac and Čepinski Martinci-Dubrava, and a $250 \mu \mathrm{m}$ sieve at Vinkovci, 14 Matije Gupca and Slavča.

The floated remains were completely sorted for plant remains at all sites and the charcoal volume for each flot was recorded. All plant remains were carbonised and were identified using a low power $\times 7-40$ binocular microscope and comparisons made from the modern reference collections at the Institute of Archaeology, University College London and the School of Archaeology and Ancient History, University of Leicester. The nomenclature of scientific plant names follows Zohary et al. (2012) for cultivars and Tutin et al. (1964-1980) for wild plants.

A standardised counting method was used, where each grain counts as one and the whole grain equivalent (WGE) was estimated for fragments of grains. This was achieved by weighting 10 whole grains of a particular species then dividing by 10 to determine the average weight of a single grain, then the weight of the fragments are converted into the equivalent number of whole grains. Glume base fragments were counted as one unless clearly representing part of another fragment, while whole spikelet forks were counted as two glume bases. The fruit and weed seeds were counted as one, even when only a fragment was found, except where large seeds were broken and clearly represented parts of the same seed, such as Cornus mas.

\section{Results}

For the purpose of this paper, the 13 study sites were examined as either an early/middle Copper Age (4500-3500 cal BC) or late Copper Age assemblage (3500-2500 cal BC) (Table 1). For the early/middle Copper Age, the sites included Barbarsko, Čepinski Martinci-Dubrava, Čeminac-Vakanjac, Jurjevac-Stara Vodenica, Lasinja, Potočani, Pajtenica-Velike Livade, Slavča, Tomašanci-Palača and Virovitica-Batelije. For the late Copper Age, the sites included Čepinski Martinci-Dubrava, Tomašanci-Palača, Đakovo-Franjevac, Slavča, Vinkovci, 14 Matije Gupca and Vučedol. Forty-five samples from Slavća were categorised as Copper Age only as the samples have not been identified yet to a particular cultural group and so could represent occupation levels from the end of the Neolithic to the late Copper Age.

\section{Early/middle Copper Age (ca. 4500-3500 cal BC)}

A total of 73 samples were examined from 11 sites containing 1486 seed items (Table 1). Seed density is particularly low at all the sites $(<1$ seed per litre), suggesting slow accumulation of plant remains within the contexts, except at Lasinja, which has a seed density of 6.1, and Slavča, which has a seed density of 10.5. Standard deviation was also low at most of the sites indicating little variation between the samples, although the following sites have a number of samples that increased their standard deviations. At Slavča, two samples have between them 349 glume wheat glume bases, at Lasinja, one sample contains 94 millet grains and at Čeminac-Vakanjac, one sample has 180 glume wheat glume bases. The average charcoal density is also extremely low $\left(<0.43 \mathrm{~cm}^{3} / 1\right)$, except at Čepinski Martinci-Dubrava, which has a charcoal density of $1.35\left(\mathrm{~cm}^{3} / 1\right)$ and Barbarsko, which has a charcoal density of $2.27\left(\mathrm{~cm}^{3} / \mathrm{l}\right)$.

Cereal grain and chaff dominate the 11 site assemblages, from $56 \%$ at Tomašanci-Palača to $99 \%$ of the remains at Slavča, followed generally by fruits, wild plants and weed species (Tables 2, 3, and 4). Of the cereals, einkorn (Triticum monococcum L. ssp. monococcum) and emmer (Triticum turgidum L. ssp. dicoccum) grain and chaff dominate many of the sites, with a large number of Triticum sp. glume bases also being recovered from Slavča and ČeminacVakanjac (Table 2). Thirteen barley grains (Hordeum vulgare ssp. vulgare) are identified from the assemblages and only one barley rachis was identified from Slavča. Of interest was the large number of foxtail millet (Setaria italica) grains from Lasinja, which were slightly larger, more rounded and less slender than Setaria viridis/verticillata.

Pulses and oil plants were rare with only one large unidentified pulse from Potočani and two possible flax seeds (Linum usitatissimum) from Čeminac-Vakanjac (Table 3). The fruit spectrum is dominated by cornelian cherry (Cornus mas), 


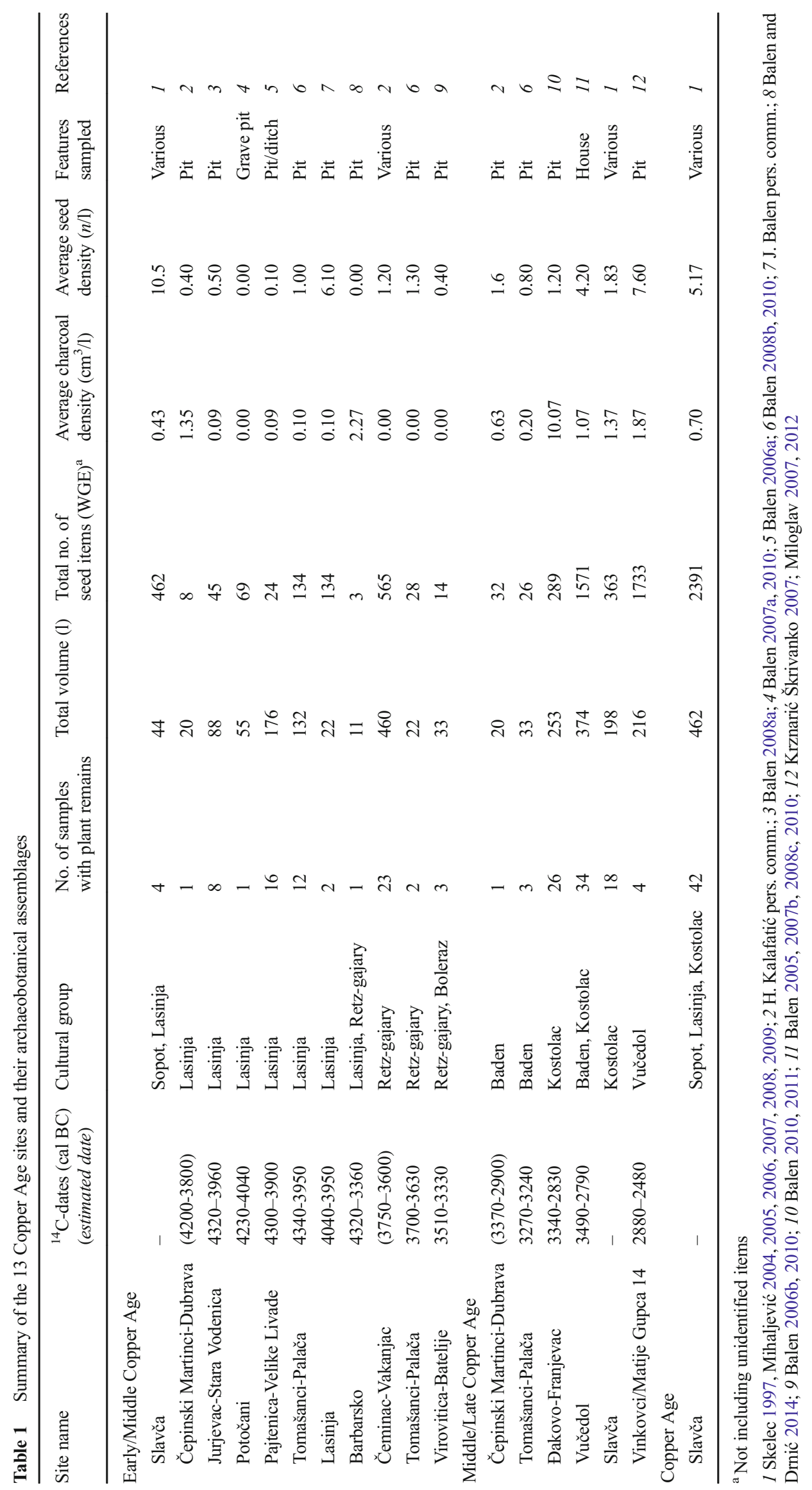




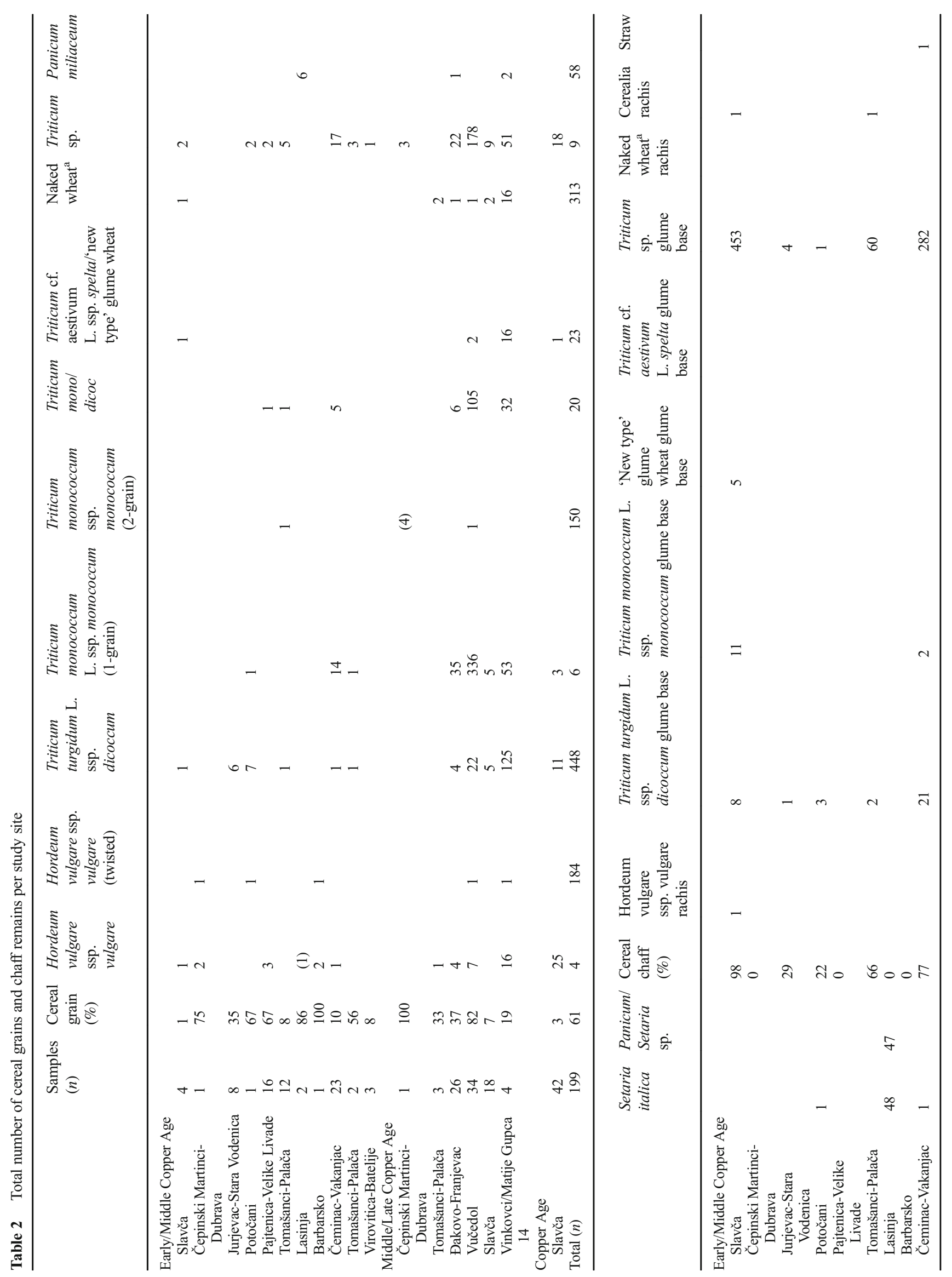




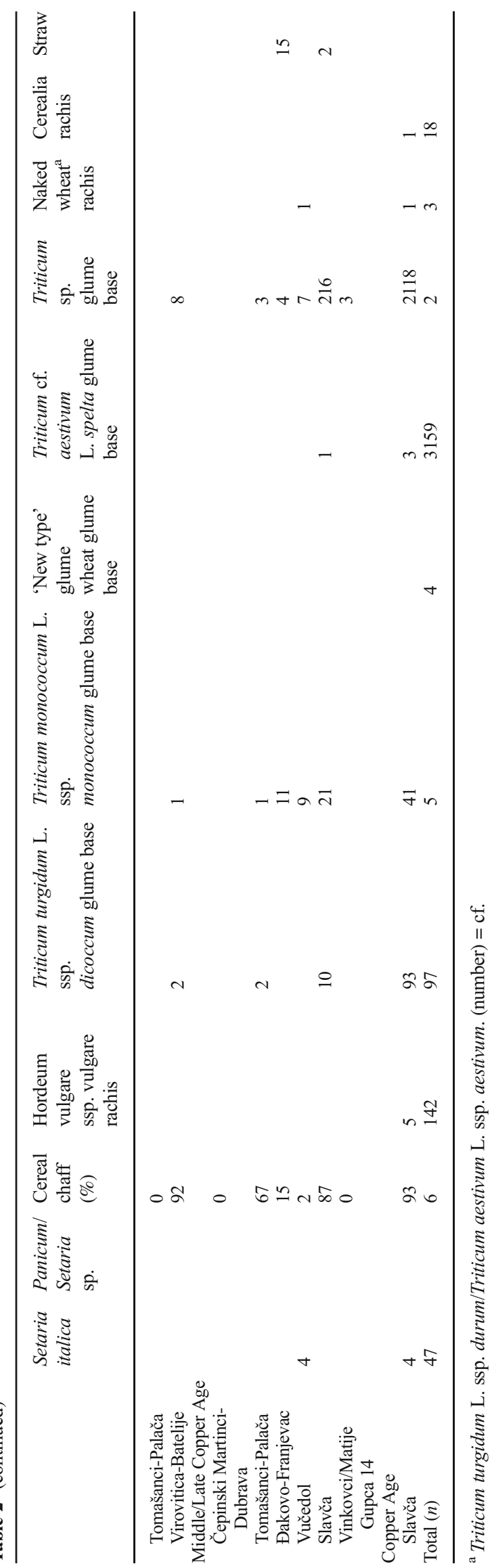

which was recovered from four of the sites, followed by chinese lantern (Physalis alkekengi), which was found at two sites (Table 3). Wild plant and weed species are not commonly identified from the sites with Čeminac-Vakanjac having the highest number at 32 seeds and 13 different species, of which grasses and dwarf elder (Sambucus ebulus) predominated (Table 4).

\section{Late Copper Age (ca. 3500-2500 cal BC)}

A total of 86 samples were examined from 6 sites containing 4002 seed items (Table 1). Seed density was generally higher than the early/middle Copper Age ranging from 0.8 at Tomašanci-Palača to 7.6 at Vinkovci/Matije Gupca 14. Standard deviation was relatively high (8.7) for Vučedol indicating variation between the samples. In particular, three samples from house floors and one sample from a burnt wall at Vučedol had high concentrations of einkorn and indeterminate cereal fragments. Charcoal density was also higher ranging from $0.2\left(\mathrm{~cm}^{3} / 1\right)$ at Tomašanci-Palača to $10.07\left(\mathrm{~cm}^{3} / 1\right)$ at Đakovo-Franjevac.

Cereal grain and chaff dominate the assemblages of all but Vinkovci/Matije Gupca 14, where $77 \%$ of the site assemblage is wild plant and weed species (Tables 2, 3, and 4). Einkorn dominates the cereal remains at Đakovo-Franjevac and Vučedol, while emmer dominates Vinkovci/Matije Gupca 14. Overall, barley is not found in high quantities with the highest number of grains, 16, being found at Vinkovci/ Matije Gupca 14 (Table 2). No barley rachis was identified for this period. At Vinkovci/Matije Gupca 14 and Vučedol, a number of possible spelt or 'new type' glume wheat grains, characterised by the blunt apex and no dorsal ridge (Jones et al. 2000; Kohler-Schneider 2003), were recovered. However, due to similarities in morphology, their poor state of preservation and the fact that no identified glume bases were recovered restricted their identification to species (Table 2). A small number of naked wheat grains (identified as Triticum turgidum L. ssp. durum/Triticum aestivum L. ssp. aestivum) were also recovered at all the sites during this period.

Pulses and oil plants are far more common, especially at Đakovo-Franjevac, which had seeds of grass pea (Lathyrus sativus), lentil (Lens culinaris) and pea (Pisum sativum), and at Vinkovci/Matije Gupca 14, where 47 flax seeds were identified (Table 3). The fruit remains were dominated by chinese lantern, which were recovered in small numbers from all four sites, as well as cornelian cherry which was identified at three of the sites (Table 3). A couple of blackberry (Rubus fruticosus) seeds were also recovered from ĐakovoFranjevac and Slavča. Wild plant and weed species are present in higher quantities at all the sites except Slavča, where only $4 \%$ of the assemblage contained wild plant and weed species (Table 4). As already noted, Vinkovci/Matije Gupca 14 has a 







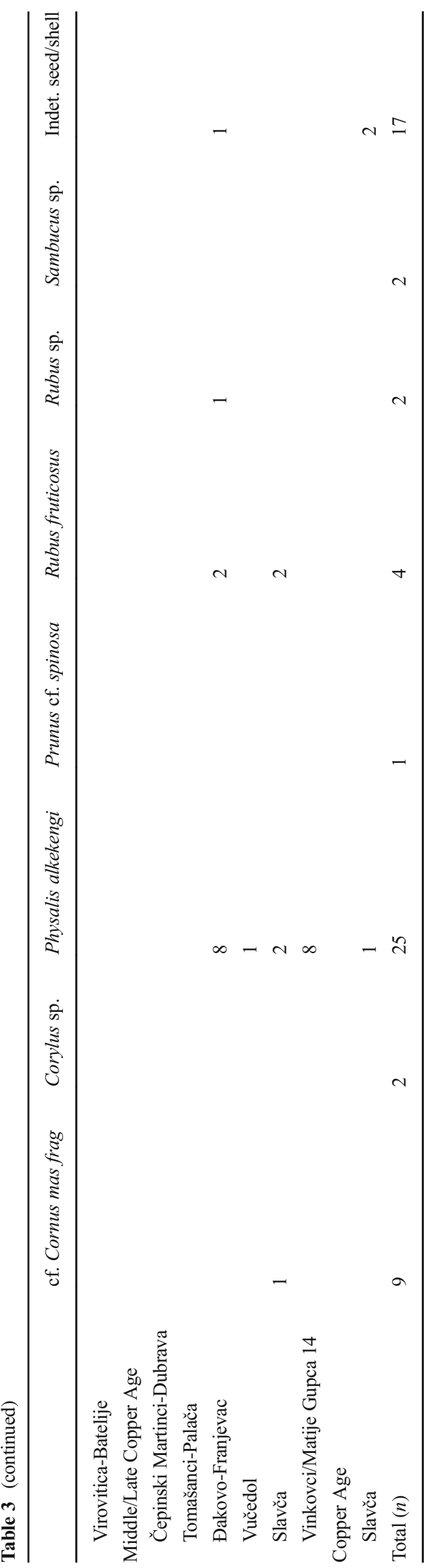

particularly high percentage, which is from the recovery of large numbers of grass species (Bromus sp., Phleum sp. etc.) and goosefoot/fat hen (Chenopodium sp./Chenopodium album), which equalled 1212 seeds (Table 4).

\section{Copper Age (4500-2500 cal BC)}

For the 42 undated Slavča samples, a total of 2391 seed items were recovered. Seed density was relatively high at 5.17 , but the charcoal density was low at $0.7\left(\mathrm{~cm}^{3} / \mathrm{l}\right)$. The chaff remains dominated, representing $93 \%$ of the assemblage. Unfortunately, due to poor preservation at the site, 2118 glume bases could not be identified to species. Where possible, einkorn, emmer and new glume wheat glume bases were identified (Jones et al. 2000; Kohler-Schneider 2003), along with five barley rachis. Of the small number of cereal grains identified, barley dominates, followed by einkorn and then emmer and one possible spelt or 'new type' glume wheat (Table 2). One lentil and one bitter vetch (Vicia ervilia) were recovered along with 13 flax seeds. Of the fruits, only one cornelian cherry and one chinese lantern seed was identified. The wild plant and weed seed spectrum is dominated by grasses and fat hen, but due to poor preservation, few seeds were able to be identified to species (Table 4).

\section{Discussion}

\section{Assessing the archaeobotanical data from continental Croatia}

The limited occurrence of archaeobotanical sampling at sites has resulted in a large gap in our understanding of agricultural development in Croatia. Where samples are taken, there is no consistency and little record of the methods used, which presents problems when analysing possible patterns between sites. The different sites examined here have a number of biases within their assemblages. Most notably is the difference in sieve sizes used between the sites, which means that smaller seeds and plant items may have been lost at Barbarsko, ĐakovoFranjevac, Jurjevac-Stara Vodenica, Lasinja, PajtenicaVelike Livade, Potočani, Tomašanci-Palača, Vučedol and Virovitica-Batelije, which used slightly larger mesh sizes (cf. Keeley 1978; Pearsall 2000). In addition, the limited range of contexts sampled will also impact the representativeness of the archaeobotanical data (Hillman 1981; Jacomet and Brombacher 2005). The bias towards pits in the Croatian assemblage, as well as the low seed density, may suggest that many of the remains represent the slow accumulation of secondary or tertiary deposits, which have little association with activities in the location of the context. This is most evident from the high 
:

m

赔

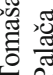

N 6

兽营

$\pi=$

a
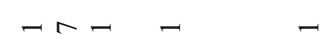

$\infty$

若

ตี้

$-0$

穿

步

敢

$\simeq \infty$

胥

㐘

ปั.

离弯

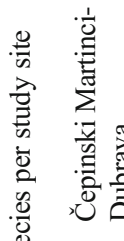

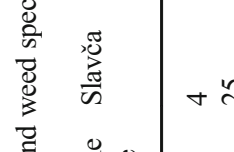

灵

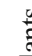

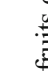

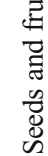

(1)

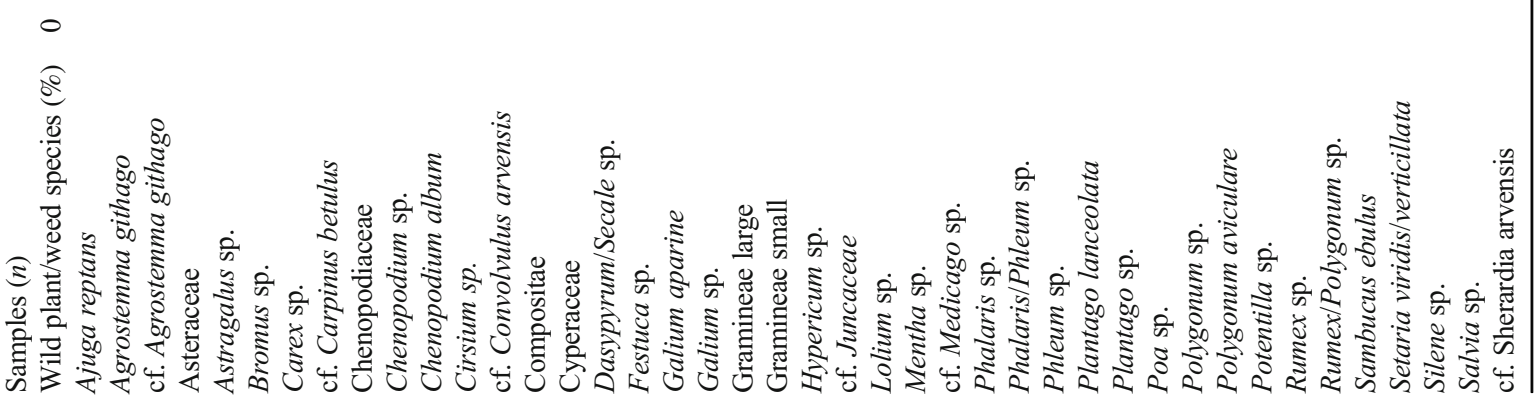




$$
\mathbb{I}
$$




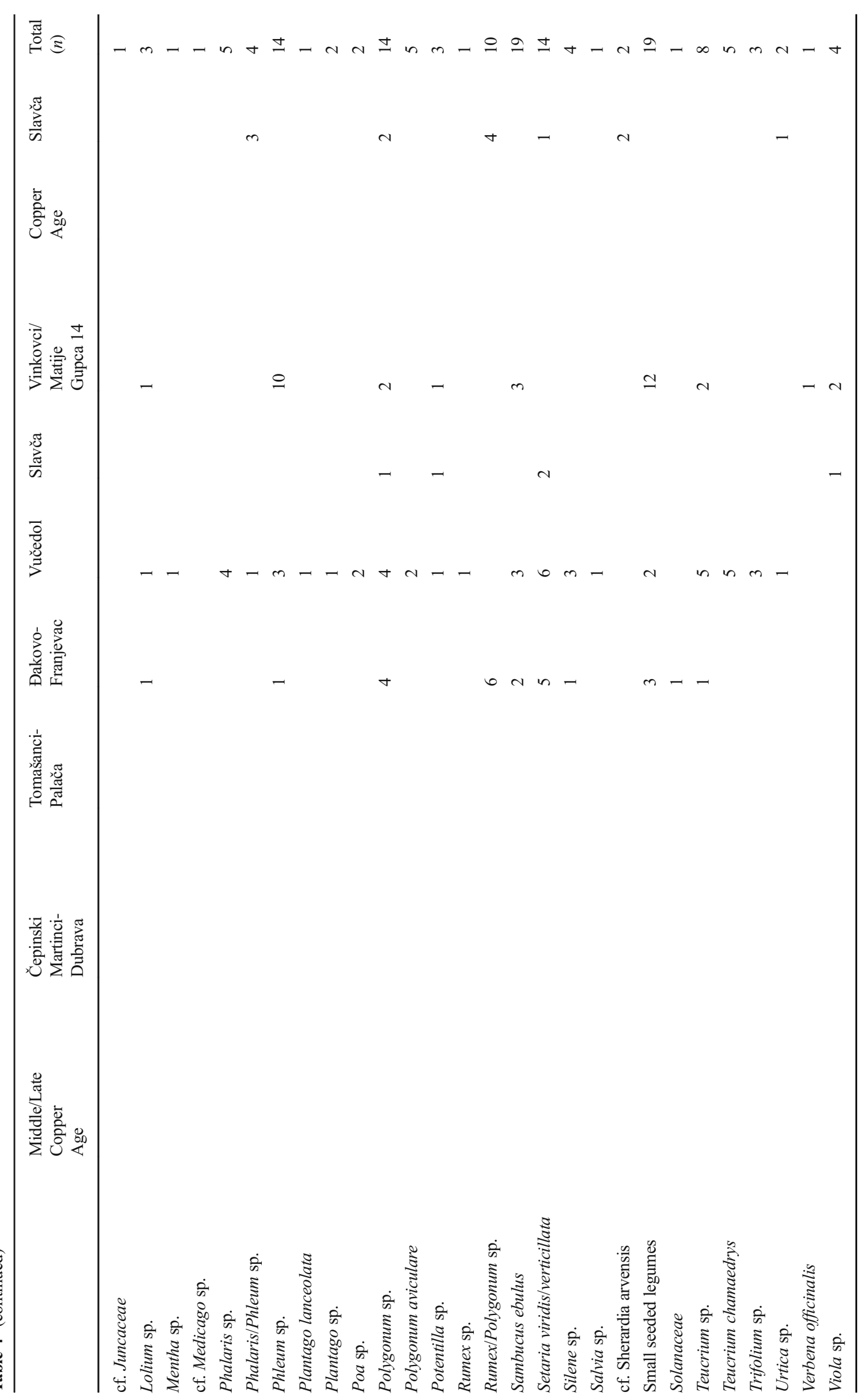


percentage of glume wheat glume bases recovered from pits at Slavča, Tomašanci-Palača, Virovitica-Batelije, which may represent crop processing by-products that were either deliberately or accidently thrown in a fire and then swept outside (Hillman 1984; Van der Veen 2007). Further bias may be seen by the lack of barley rachis within the Croatian assemblages, where its absence may not necessarily suggest its absence as a crop but rather that barley was processed away from the settlement or did not survive the carbonisation process (cf. Dennell 1976; Hillman 1981). The movement of remains through contexts has also been recently demonstrated from the dating of broomcorn millet that turned out to be younger than their contexts suggested (Motuzaite-Matuzeviciute et al. 2013). The anomalous foxtail millet remains from one sample at Lasinja may therefore represent younger remains, especially as foxtail millet is only identified as a minor crop from the Iron Age onwards (Bakels 2013; Schmidl et al. 2007).

Another consideration is the differences in site formation, as the greatest numbers of identified plant items as well as the greatest range of species identified were from Vučedol, Slavča and Vinkovci/Matije Gupca 14, which are all sites where either higher concentrations of occupation are present or where the successive layers of occupation permitted greater preservation. In contrast, many of the other sites were excavated as part of rescue excavations, which in some cases limited the number of samples collected, and many were located in agricultural fields that were heavily ploughed, making sampling only possible from pit features (e.g. Jurjevac-Stara Vodenica, Pajtenica-Velike Livade, Tomašanci-Palača and ĐakovoFranjevac).

Comparison between the study sites in terms of crop importance is also difficult as the particularly low numbers of plant remains identified at the majority of the sites restricts interpretation beyond the presence of species. According to van der Veen and Fieller (1982), every sample requires at least 384 items, with one taxon making up $50 \%$ of the assemblage, to ensure a $95 \%$ chance of estimating the contribution of each taxon. Samples with fewer than 50 or 100 items are also excluded from crop processing and husbandry analysis (Bogaard 2004; Valamoti 2004; Van der Veen 1992). The exact importance of each taxon in these assemblages is therefore questionable, especially as only two samples from Vinkovci/Matije Gupca 14 have over 384 plant remains, and these are dominated by brome grass (Bromus sp.) and fat hen (Chenopodium album), and one sample at Vučedol which has a large number of unidentified cereal remains. As a result, the data will be examined below at the macrolevel in order to examine general patterns between continental Croatia and the neighbouring regions of Hungary and Serbia.

\section{The Neolithic/Copper Age transition: continuation or change in crop agriculture?}

In continental Croatia, archaeobotanical data from the late Neolithic is also relatively sparse, with only eight sites providing evidence (Burić 2007:45-46; Đukić 2014; Obelić et al. 2002; Reed 2015). From the data collected, the most frequent and abundant crops, in terms of no. of identified items, were einkorn and emmer (Fig. 4; Table 5). To a lesser extent barley, lentil, pea and flax, as well as the fruits cornelian cherry (Cornus mas) and chinese lantern (Physalis alkekengi) were also recorded for the period (Reed 2015). Whether this pattern continues into the early/middle Copper Age in Croatia is difficult to say with such a limited number of identified remains. From the 46 grains of emmer, barley and einkorn, the proportions are relatively similar, although the frequency of barley seems to increase (Fig. 4; Table 5).

In neighbouring Hungary, the archaeobotanical data for the late Neolithic is slightly larger with 18 sites producing archaeobotanical remains (Gyulai 2010). Barley is the most frequently found, followed by emmer, then einkorn and naked wheat (Table 5). Proportionally, the number of grains recovered is greatest for emmer (Fig. 4); however, this is due to over 16,000 emmer grains being recovered from late Neolithic Tiszapolgár-Csőszhalom. With that site removed, the proportion of barley grains recovered is slightly higher than emmer. Few chaff remains seem to have been identified to species and probably indicates poor preservation at the sites, whether through pre or post depositional processes. In addition to the cereals, pulses and oil plants are also identified, with lentil and pea being the most frequently recovered. A slight increase in the frequency of barley as well as the proportion of barley grains may be seen for the early/middle Copper Age (Table 5, Fig. 4). However, this is based on only 105 grains of barley, emmer and einkorn (Fig. 4) and 7 sites where the highest concentration of only 30 grains of barley were recovered from Rákoskeresztúr-Újmajor, near Budapest (Gyulai 2010). Other crop items are rare, although a small number of lentil and flax were also identified for this period.

In Serbia, only 10 sites have provided archaeobotanical data for the late Neolithic Vinča culture (Filipović and Obradović 2013). Einkorn and emmer appear most frequently at the majority of sites followed less often by naked wheat and hulled barley (ibid.). Similar to continental Croatia and Hungary, lentil, pea and flax are also frequently identified at the sites. Unfortunately, only the one late Copper Age site, Gomolava (Van Zeist 2003), has evidence of archaeobotanical remains from Serbia, so no patterns can be seen between the late Neolithic and early/ middle Copper Age. This pattern is also seen in Bosnia and Herzegovina, where emmer and einkorn are more frequently recovered during the late Neolithic, followed by barley, naked wheat, lentil, pea and flax, but no 
Fig. 4 Proportion of einkorn, emmer and barley grains per period for continental Croatia and Hungary

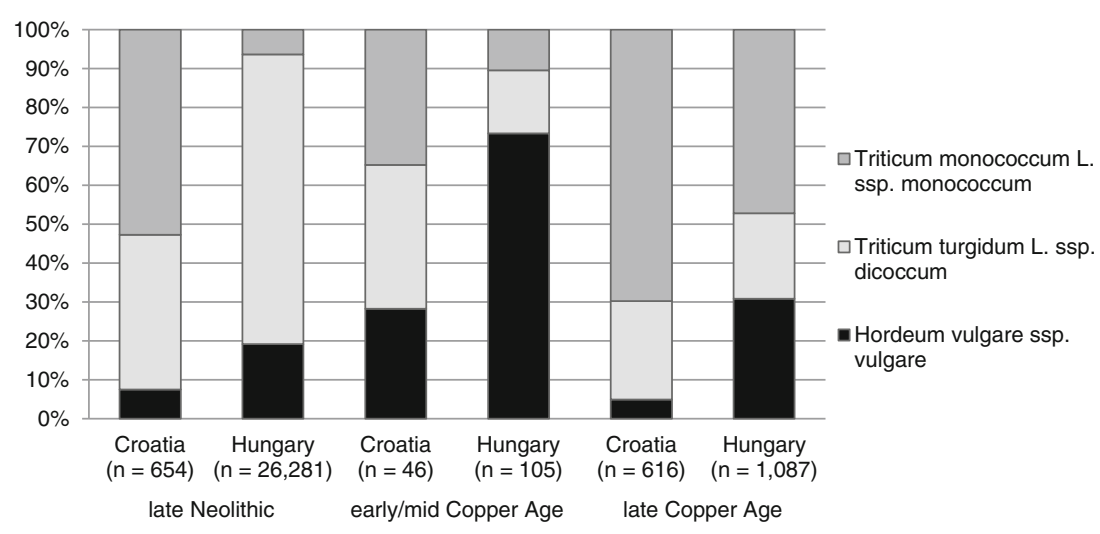

early/middle Copper Age data currently exists (Reed 2013: Chapter 8).

Comparing continental Croatia and Hungary, where there is evidence of both late Neolithic and early/middle Copper
Age plant remains, there is a clear reduction in the quantity and range of plant items recovered from both regions. This has been suggested as evidence of a reduction in the production of arable crops during the early/middle Copper Age (Gyulai
Table 5 Crop frequency per site in continental Croatia and Hungary for the late Neolithic to late Copper Age (undated sites are excluded)

\begin{tabular}{|c|c|c|c|c|c|c|}
\hline & \multicolumn{2}{|c|}{ Late Neolithic } & \multicolumn{2}{|c|}{$\begin{array}{l}\text { Early/Mid Copper } \\
\text { Age }\end{array}$} & \multicolumn{2}{|c|}{ Late Copper Age } \\
\hline & Croatia & Hungary & Croatia & Hungary & Croatia & Hungary \\
\hline No. of sites & 8 & 18 & 11 & 13 & 6 & 13 \\
\hline \multicolumn{7}{|l|}{ Cereal grain } \\
\hline Hordeum vulgare ssp. vulgare & $25 \%$ & $44 \%$ & $64 \%$ & $54 \%$ & $67 \%$ & $92 \%$ \\
\hline Triticum turgidum L. ssp. dicoccum & $63 \%$ & $38 \%$ & $55 \%$ & $31 \%$ & $67 \%$ & $69 \%$ \\
\hline $\begin{array}{l}\text { Triticum monococcum ssp. monococcum } \\
\text { (2-grain) }\end{array}$ & $63 \%$ & $27 \%$ & $36 \%$ & $23 \%$ & $67 \%$ & $38 \%$ \\
\hline Triticum aestivum L. ssp. spelta & $25 \%$ & $11 \%$ & & & & $8 \%$ \\
\hline $\begin{array}{l}\text { Triticum aestivum L. ssp. spelta/'new } \\
\text { type' glume wheat }\end{array}$ & & & $9 \%$ & & $33 \%$ & \\
\hline Naked wheat ${ }^{\mathrm{a}}$ & $50 \%$ & $27 \%$ & $9 \%$ & & $83 \%$ & $31 \%$ \\
\hline Panicum miliaceum & $13 \%$ & $22 \%$ & $9 \%$ & $15 \%$ & $33 \%$ & $8 \%$ \\
\hline Setaria italica & $13 \%$ & & $27 \%$ & & $17 \%$ & \\
\hline \multicolumn{7}{|l|}{ Cereal chaff } \\
\hline Hordeum vulgare ssp. vulgare rachis & $13 \%$ & $11 \%$ & $9 \%$ & & & $15 \%$ \\
\hline $\begin{array}{l}\text { Triticum turgidum L. ssp. dicoccum } \\
\text { glume base }\end{array}$ & $38 \%$ & & $55 \%$ & $23 \%$ & $33 \%$ & $54 \%$ \\
\hline $\begin{array}{l}\text { Triticum monococcum L. ssp. } \\
\text { monococcum glume base }\end{array}$ & $38 \%$ & & $27 \%$ & $15 \%$ & $67 \%$ & $31 \%$ \\
\hline $\begin{array}{l}\text { Triticum cf. aestivum L. spelta } \\
\text { glume base }\end{array}$ & $25 \%$ & & $9 \%$ & & $17 \%$ & $8 \%$ \\
\hline 'New type' glume wheat glume base & & & & & $17 \%$ & $8 \%$ \\
\hline Naked wheat ${ }^{\mathrm{a}}$ rachis & $25 \%$ & & & & & \\
\hline \multicolumn{7}{|l|}{ Pulses } \\
\hline Lathyrus sativus & $13 \%$ & $11 \%$ & & & $17 \%$ & \\
\hline Lens culinaris & $50 \%$ & $16 \%$ & & $8 \%$ & $17 \%$ & \\
\hline Pisum sativum & $38 \%$ & $33 \%$ & & & $33 \%$ & $8 \%$ \\
\hline Vicia ervilia & $13 \%$ & $5 \%$ & & & & \\
\hline \multicolumn{7}{|l|}{ Oil Plants } \\
\hline Camelina sativa & & $5 \%$ & & & & \\
\hline Linum usitatissimum & $25 \%$ & $5 \%$ & $9 \%$ & $8 \%$ & $67 \%$ & \\
\hline
\end{tabular}


2010: 87). However, the low recovery of archaeobotanical remains does not necessarily correlate with a reduction in crop agriculture for a number of reasons. First, as seen with the Croatian samples, inconsistent recovery techniques in the region will impact on the quality and quantity of remains recovered. Second, the process of carbonisation itself only allows a small fraction of the local plant spectra to be preserved; therefore, the carbonised remains will only ever provide a limited view on the crop agriculture of a settlement. Third, the preservation of remains at flat open-air settlements can be particularly low compared with the larger multi-generational tell sites of the late Neolithic, and so a reduction in plant items could be a result of site formation processes.

The slightly higher presence of barley seen in the first half of the Copper Age in Hungary has also been linked to hulled barley's greater tolerance of environmental extremes (Ceccarelli et al. 2001; Lister and Jones 2013), thus responding better to possible deteriorating environmental conditions especially seen during the onset of sub-boreal. These fluctuating climatic conditions have been noted in Slovakia where a dry period persists at the end of the late Neolithic, shifting back to a more humid climate ca. 4000 to $3500 \mathrm{BC}$, followed by drought conditions ca. 3500 to $3000 \mathrm{BC}$, finally shifting back to humid condition for the end of the Copper Age (Tóth et al. 2011). In Hungary, interpreting climatic fluctuations can be difficult with two major climatic boundaries roughly corresponding with the Great Hungarian Plain (to the east), which is arid and continental, and Transdanubia (to the west), which is more humid and moderate (Nagy-Bodor et al. 2000). Thus, during the sub-boreal, which occurred ca. 3000 cal BC, the Great Hungarian Plain became more arid, while precipitation increased in Transdanubia (ibid.). However, fluctuations existed as paleontological evidence dating to the start of the Copper Age in eastern Hungary suggests that the local alluvium was moister than the preceding Neolithic, although with less pronounced fluctuations in the summer water table (Magyari et al. 2012). RákoskeresztúrÚjmajor, which had the highest number of barley grains, is located roughly in the middle of these two climatic zones, making it unclear how these changing environments may have impacted on crop growing, especially as huge variations likely existed across the complex networks of swamps, seasonally flooded alluvial soils and micro-climates that make up Hungary.

Settlement locations do not seem to change radically between the late Neolithic and early/middle Copper Age in continental Croatia. Within the vicinity of most of the Copper Age sites is a Neolithic settlement (e.g. Vinkovci/Matije Gupca 14 is a couple of miles north of the Neolithic tell site of Sopot), and all are located on alluvial plains, near watercourses, where agriculture is still practiced today. In Hungary too, studies show a continuation in settlement locations from the late Neolithic, predominantly along active watercourses (Gyucha et al. 2009; 2011). It is suggested that fields, whether for crops or pasture, were located more on the Pleistocene levees, while the seasonally flooded alluvium was only opportunistically exploited for crop farming (Magyari et al. 2012). Exploitation of these floodplains may therefore explain the recovery of non-cereal based food sources (e.g. nutlets of Scheonoplectus lacustris) and other water/marsh plants seen at early/middle Copper Age sites (Gyulai 2010: 87-90). Unfortunately, methods to examine what crop husbandry regimes may have been practiced (i.e. weeding, manuring, tillage) in the region are restricted by poor quality datasets (see Bogaard 2004; Kreuz and Schäfer 2011 for reconstructions at Neolithic sites in central Europe). However, the continuation of crop agriculture would tie in with the recent isotope and lipid residue analysis, which suggested the emergence of smaller independent farmsteads with a similar herding strategy to that of the late Neolithic (Giblin 2009, 2014; Giblin et al. 2013, Hoekman-Sites and Giblin 2012).

\section{Late Copper Age agricultural development (ca. 3500 to 2500 cal $\mathrm{BC}$ )}

By the late Copper Age, einkorn is recovered in greater quantities in continental Croatia, although the majority are from Vučedol, while the frequency of barley, emmer and einkorn is the same (Table 5, Fig. 4). The chaff remains are dominated by emmer and einkorn glume wheat glume bases, but as already discussed above this may be preservation bias rather than an indication that barley was not cultivated as a crop. A greater variety and quantity of plants are recovered for this period; however, this is likely due to formation processes at the sites, particularly at Slavča, Vučedol and Vinkovci/Matije Gupca 14, rather than a difference in crop husbandry methods.

In Hungary, a particularly high barley frequency is seen for the late Copper Age (Table 5), though a higher number of einkorn grains were identified overall (Fig. 4). Similar to the earlier phase, many of the sites have only a handful of grains, with only Györ-Szabadrétdomb and Budapest, AlbertfalvaKitérő út having over 100 grains of barley and Budapest, Albertfalva-Kitérö út having 449 of the einkorn grains recovered from the period (Gyulai 2010). Pulses are still relatively rare and no oil plants have been positively identified.

In Serbia, only Gomolava has provided any archaeobotanical data. Here, there seems to be a similar percentage of barley and einkorn grains recovered, followed less often by emmer, broomcorn millet and naked wheat (van Zeist 2003). Of the other possible crops, only a few pulses of lentil and bitter vetch, as well as only one flax seed, were identified.

Once again, the relatively low number of plant remains recovered and low numbers of samples from each site prevent any further analysis of the possible agricultural regimes. Overall, the range and quantity of cereals and pulses are similar to that of the late Neolithic. With these similarities, it is 
therefore unclear how the sub-boreal (ca. 3000 BC) may have impacted on crop agriculture in the region. The zooarchaeological data is also limited during the late Copper Age making reconstructions of possible pastoral regimes difficult (Arnold and Greenfield 2006: 122).

\section{Conclusion}

This study presents archaeobotanical evidence for crop agriculture during the Copper Age in continental Croatia. From the results, the low quantity and diversity of plant remains, particularly for the early/middle Copper Age, is likely due to factors such as poor preservation, site formation and sampling strategies rather than a reduction in crop agriculture. The dataset highlights the difficulties in comparing sites with different sampling strategies and problems that can arise when interpreting crop husbandry regimes based on low quantities of plant remains. Thus, no clear differences in crop cultivation were seen between the different sites and further work is needed in collecting more archaeobotanical data.

That being said when examining the data at the macroscale general patterns may be seen. For instance, similarities with late Neolithic assemblages are seen in terms of the range and numbers of plant remains, where the main crops cultivated were likely emmer and einkorn and to a lesser extent barley. Less frequently, millet, naked wheat and spelt/new glume wheat are also found, especially at the late Copper Age sites; however, due to their low numbers, it is unclear whether these represent crops in their own right or were weeds within the main crops. Pulses (e.g. lentil, pea and grass pea), fruit remains (e.g. cornelian cherry and chinese lantern) and wild plant and weed seeds are also recovered, although again more commonly from the late Copper Age sites.

In conclusion, the continuation in crop agriculture inferred from the data presented here and the fact that recent archaeological evidence advocates small-scale animal husbandry regimes Giblin 2009; Giblin et al. 2013, Hoekman-Sites and Giblin 2012) would suggest that agro-pastoral regimes did not change dramatically in light of socio-economic or climatic changes seen during the Copper Age. It is therefore proposed that an agro-pastoral regime dominated in continental Croatia with an equal focus on crops and animal husbandry during the Copper Age, although variations are likely to have existed between the sites.

Acknowledgments This research was partially funded by Arts and Humanities Research Council (AHRC). I wish to thank Jacqueline Balen, Hrvoje Kalafatić, Maja Krznarić Škrivanko, Hrvoje Vulić and Marija Mihaljević for allowing me to collect and use their archaeobotanical material and for all their help and support over the years. Many thanks to Sue College and Marijke van der Veen for their helpful advice while undertaking my $\mathrm{PhD}$ and the Departments of Archaeology at UCL and University of Leicester for allowing me to use their reference collections. Thanks to David Orton and Dragana Filipović for providing references for Serbia. I also wish to thank the two anonymous referees who provided valuable comments on an earlier version of the manuscript.

Open Access This article is distributed under the terms of the ?Creative Commons Attribution 4.0 International License (http:// creativecommons.org/licenses/by/4.0/), which permits unrestricted use, distribution, and reproduction in any medium, provided you give appropriate credit to the original author(s) and the source, provide a link to the Creative Commons license, and indicate if changes were made.

\section{References}

Akeret Ö (2005) Plant remains from a Bell Beaker site in Switzerland, and the beginnings of Triticum spelta (spelt) cultivation in Europe. Veg Hist Archaeobot 14(4):279-286

Anthony D (2007) The horse, the wheel, and language: how bronze-age riders from the Eurasian steppes shaped the modern world. Princeton University Press, Princeton

Antonović D (2009) Prehistoric copper tools from the territory of Serbia. J Min Metall 45(2):165-174

Arnold ER, Greenfield HJ (2006) The origins of transhumant pastoralism in temperate Southeastern Europe: a zooarchaeological perspective from the Central Balkans, BAR, International Series No. 1538. Archaeopress, Oxford

Bakels CC (2013) Foxtail millet (Setaria italica [L.] P.Beauv.) in Western Central Europe. In: Von Carnap-Bornheim C, Dörfler W, Kirleis W, Müller J, Müller U (eds) Von Sylt Bis Kastanas, Offa 69/70. Wachholtz Verlag Neumünster, Neumünster, pp. 139-145

Balen J (2002) The topography of the Kostolac Culture in Northern Croatia. Vjesnik Arheološkog Muzeja u Zagrebu 35(1):35-52

Balen J (2005) The Kostolac horizon at Vučedol. Opvscvla Archaeologica 29(1):25-40

Balen J (2006a) Pajtenica-Velike Livade. In: Mesić J (ed) Hrvatski Arheološki Godišnjak, 3. Ministarstvo Kulture, Zagreb, pp. 27-29

Balen J (2006b) Virovitica-Batelije. In: Mesić J (ed) Hrvatski Arheološki Godišnjak, 3. Ministarstvo Kulture, Zagreb, pp. 103-104

Balen J (2007a) Gornji Vrhovci, Potočani. In: Blanda M, Potrebica H (eds) Hrvatski Arheološki Godišnjak, 4. Ministarstvo Kulture, Zagreb, pp. 116-119

Balen J (2007b) Vučedol. In: M. Blanda (ed) Hrvatski Arheološki Godišnjak. 4. Ministarstvo Kulture, Zagreb, pp 85-87

Balen J (2008a) Jurjevac - Stara Vodenica. In: Mesić J (ed) Hrvatski Arheološki Godišnjak, 5. Ministarstvo Kulture, Zagreb, pp. 56-58

Balen J (2008b) Tomašanci-Palača. In: Mesić J (ed) Hrvatski Arheološki Godišnjak, 5. Ministarstvo Kulture, Zagreb, pp. 60-62

Balen J (2008c) Vučedol. In: Mesić J (ed) Hrvatski Arheološki Godišnjak, 5. Ministarstvo Kulture, Zagreb, pp. 107-110

Balen J (2010) Eneolitičke kulture na prostoru istočne Hrvatske / Eneolithic cultures in the territory of eastern Croatia, neobjavljena doktorska disertacija / unpublished PhD thesis, Zagreb, 2010

Balen J (2011) Đakovo-Franjevac: Late Eneolithic site, Musei Archaeologici Zagrabiensis Catalogi et Monographiae Vol VII. Arheološki muzej u Zagrebu, Zagreb

Balen J, Drnić I (2014) Archaeological excavations at Barbarsko-a new contribution to understanding of the middle copper age in northern Croatia. Vjesnik Arheološkog Muzeja u Zagrebu 47(1):39-76

Balesse M, Bălășescu M, Tornero C, Fremondeau D, Hovsepyan R, Gillis R, Popovici D (2015) Investigating the scale of herding in Chalcolithic pastoral communities settled along the Danube River 
in the 5th millennium BC: A case study at Borduşani-Popină and Hârșova-tell (Romania). Quat Int. doi:10.1016/j.quaint.2015.07.030

Bánffy E (1994) Transdanubia and Eastern Hungary in the Early Copper Age-Dunántúl és Kelet-Magyar-orzág a kora rézkorban. Jósa András Múzeum Évkönyve 36:291-296

Bartosiewicz L (2005) Plain talk: animals, environment and culture in the Neolithic of the Carpathian basin and adjacent areas. In: Bailey D, Whittle A (eds) (Un)settling the Neolithic. Oxbow Books, Oxford, pp. $51-63$

Bogaard A (2004) Neolithic farming in Central Europe: an archaeobotanical study of crop husbandry practices. Routledge, London

Bognar-Kutzian I (1963) The Copper Age Cemetery of TiszapolgarBasatanya. Archaeologica Hungarica Akademiai Kiado, Budapest

Bognar-Kutzian I (1972) The Early Copper Age Tiszapolgar Culture in the Carpathian Basin. Archaeologica Hungarica Akademiai Kiado, Budapest

Bogucki P (1993) Animal traction and household economies in Neolithic Europe. Antiquity 67:492-503

Bökönyi S (1974) History of domestic mammals in Central and Eastern Europe. Akademiai Kiado, Budapest

Borojević K, Forenbaher S, Kaiser T, Berna F (2008) Plant use at Grapčeva cave and in the eastern Adriatic Neolithic. J Field Archaeol 33(3):279-303

Burić M (2007) Bapska-Gradac. In: Blanda M (ed) Hrvatski arheološki godišnjak. 4. Ministarstvo Kulture, Zagreb, pp. 45-46

Ceccarelli S, Grando S, Bailey E, Amri A, El-Felah M, Nassif F, Rezgui S, Yahyaoui A (2001) Farmer participation in barley breeding in Syria, Morocco and Tunisia. Euphytica 122(3):521-536

Chapman J (1981) The Vinča culture of South-East Europe: studies in chronology, economy and society, BAR, International Series no.117. Archaeopress, Oxford

Chapman J (2000) Fragmentation in Archaeology: Peoples, Places and Broken Objects in the Prehistory of South Eastern Europe. Routledge, London

Ciută EB (2009) Cultivators or Shepherds? New archaeobotanical data regarding plants cultivation within Aeneolithic-Bronze Age communities, located in the Romanian Intra Carpathian area. Acta Terrae Septemcastrensis VIII:169-180

Copley MS, Berstan R, Dudd SN, Docherty G, Mukherjee AJ, Straker V, Payne S, Evershed RP (2003) Direct chemical evidence for widespread dairying in prehistoric Britain. Proc Natl Acad Sci U S A 100(4):1524-1529

Craig OE, Chapman J, Figler A, Patay P, Taylor G, Collins MJ (2003) 'Milk jugs' and other myths of the Copper Age of Central Europe. Eur J Archaeol 6(3):251-265

Craig OE, Chapman J, Heron C, Willis LH, Bartosiewitz L, Taylor G, Whittle A, Collins M (2005) Did the first farmers of Central and Eastern Europe produce dairy foods? Antiquity 79(306):882-894

Culiberg M, Horvat M, Šercelj A (1992) Karpološke in antrakotomske analize rastlinskih ostankov iz neolitske jamske nekropole Ajdovska jama. Poročilo o Raziskovanju Paleolita, Neolita in Eneolita v Sloveniji 20:111-126

Dennell RW (1976) The economic importance of plant resources represented on archaeological sites. J Archaeol Sci 3:229-247

Đukić A (2014) Biljni ostaci s četiri novoistraživana lokaliteta Đakovštine. Vjesnik Arheološkog Muzeja u Zagrebu 47(1):7-37

Durman A (1995) Psihologija naseljavanja telova. Histria Antiqua 1:153158

Evershed RP, Payne S, Sherratt AG, Copley MS, Coolidge J, Urem-Kotsu D, Kotsakis K, Ozdogan M, Ozdogan AE, Nieuwenhuyse O, Akkermans PMMG, Bailey D, Andeescu RR, Campbell S, Farid S, Hodder I, Yalman N, Ozbasaran M, Bicakci E, Garfinkel Y, Levy T, Burton MM (2008) Earliest date for milk use in the Near East and southeastern Europe linked to cattle herding. Nature 455(7212):528-531
Filipović D, Obradović Đ (2013) Archaeobotany at Neolithic Sites in Serbia: A Critical Overview of the Methods and Results. In Miladinović-Radmilović N, Vitezović S (eds) Bioarheologija na Balkanu: bilans i perspektive. Srpsko Arheološko Društvo, Beograd, pp. 25-55

Forenbaher S (1994) The Late Copper Age architecture at Vučedol, Croatia. J Field Archaeol 21(3):307-323

Foxhall L (1995) Bronze to iron: agricultural systems and political structures in late Bronze Age and early Iron Age Greece. Ann Br Sch Athens 90:239-250

Gardner AR (2002) Neolithic to Copper Age woodland impacts in northeast Hungary? Evidence from the pollen and sediment chemistry records. The Holocene 12(5):541-553

Giblin JI (2009) Strontium isotope analysis of Neolithic and Copper Age populations on the Great Hungarian Plain. J Archaeol Sci 36(2): 491-497

Giblin JI (2014) Herd mobility and secondary product exploitation in eastern Hungary during the Neolithic and Copper Age: strontium isotope analysis from zooarchaeological samples. In: Greenfield HJ (ed) Animal Secondary Products. Oxbow, Oxford, pp. 253-272

Giblin JI, Knudson KJ, Bereczki Z, Pálfi G, Pap I (2013) Strontium isotope analysis and human mobility during the Neolithic and Copper Age: a case study from the Great Hungarian Plain. J Archaeol Sci 40:227-239

Greenfield HJ (2010) The secondary products revolution: the past, the present and the future. World Archaeol 42(1):29-54

Greenfield HJ, Arnold E (2015) Go(a)t milk? New perspectives on the zooarchaeological evidence for the earliest intensification of dairying in south eastern Europe'. World Archaeol. doi:10.1080/ 00438243.2015.1029076

Gyucha A, Parkinson WA, Yerkes RW (2009) A multi-scalar approach to settlement pattern analysis: the transition from the Late Neo-lithic to the Early Copper Age on the Great Hungarian Plain. In: Thurston TL, Salisbury RB (eds) Reimagining Regional Analyses: The Archaeology of Spatial and Social Dynamics. Cambridge Scholars Publishing, Newcastle, pp. 100-129

Gyucha A, Duffy PR, Frolkingt A (2011) The KörösBasin from the Neolithic to the Hapsburgs: linking settlement distributions with pre-regulation hydrology through multiple dataset overlay. Geoarchaeology 26:392-419

Gyucha A, Duffy PR, Parkinson W (2013) Prehistoric humanenvironmental interactions on the Great Hungarian Plain. l'Anthropologie 51(2):157-168

Gyucha A, Parkinson WA, Yerkes RW (2014) The Transition from the Late Neolithic to the Early Copper Age: multi-disciplinary Investigations in the Körös Region of the Great Hungarian Plain. In: Schier W, Drasovean F (eds) The Neolithic and Eneolithic in Southeast Europe: new approaches to dating and cultural dynamics in the 6th to 4th Millennium BC, Prähistorische Archäologie in Südosteuropa, Band, vol 28. Verlag Marie Leidorf $\mathrm{GmbH}$, Rahden/Westf, pp. 273-296

Gyulai F (1993) Environment and agriculture in Bronze Age Hungary. Archaeolingua, Budapest

Gyulai F (2010) Archaeobotany in Hungary: seed, fruit, food and beverage remains in the Carpathian Basin from the Neolithic to the Late Middle Ages. Archaeolingua, Budapest

Hajnalová E (2007) Early farming in Slovakia: an archaeobotanical perspective. In: Colledge S, Conolly J (eds) The origins and spread of domestic plants in southwest Asia and Europe. Left Coast Press, Walnut Creek, pp. 295-312

Halstead P (1987) Traditional and ancient rural economy in Mediterranean Europe: plus ça change? J Hell Stud 107:77-87

Halstead P (1989) The economy has a normal surplus: economic stability and social change among early farming communities of Thessaly, Greece. In: Halstead P, O'Shea J (eds) Bad Year Economics: 
Cultural Responses to Risk and Uncertainty. Cambridge University Press, Cambridge, pp. 68-80

Halstead P (1992) Agriculture in the Bronze Age Aegean: towards a model of palatial economy. In: Wells B (ed) Agriculture in Ancient Greece. Proceedings of the 7th International Symposium at the Swedish Institute of Athens, 16-17 May 1990, Stockholm, pp 105-116

Halstead P (1995a) Late Bronze Age Grain Crops and Linear B Ideograms *65, *120, and *121. Ann Br Sch Athens 90:229-234

Halstead P (1995b) Plough and power: the economic and social significance of cultivation with the ox-drawn ard in the Mediterranean. Bull Sumer Agric 8:11-22

Hillman G (1981) Reconstructing crop husbandry practices from charred remains of crops. In: Mercer R (ed) Farming Practices in British Prehistory. Edinburgh University Press, Edinburgh, pp. 123-162

Hillman G (1984) Interpretation of archaeological plant remains: the application of ethnographic models from Turkey. In: Van Zeist W, Casparie WA (eds) Plants and Ancient Man: Studies in Palaeoethnobotany. Balkema, Rotterdam pp, pp. 1-41

Hoekman-Sites HA, Giblin JI (2012) Prehistoric animal use on the Great Hungarian Plain: a synthesis of isotope and residue analyses from the Neolithic and Copper Age. J Anthropol Archaeol 31:515-527

Horváth T (2010) Transcendent phenomena in the Late Copper Age Boleráz/Baden settlement uncovered at Balatonőszöd- Temetői dülő: human and animal "depositions". J Neolithic Archaeol 12:179

Horváth LA, Virág ZM (2003) History of the Copper Age. In: Visy S (ed) Hungarian Archaeology at the Turn of the Millennium. Ministry of National Cultural Heritage, Budapest, pp. 125-127

Huntley J (1996) The plant remains. In: Chapman J, Shiel R, Batović Š (eds) The changing face of Dalmatia. Leicester University Press, Leicester, pp. 204-205

Jacomet S (2008) Subsistenz und Landnutzung während des 3. Jahrtausends v. Chr. aufgrund von archäobotanischen Daten aus dem südwestlichen Mitteleuropa. In: Dörfler W, Müller J (eds) Umwelt - Wirtschaft - Siedlungen im dritten vorchristlichen Jahrtausend Mitteleuropas und Südskandinaviens. Offa-Bücher 84, Neumünster, pp 355-377

Jacomet S, Brombacher C (2005) Reconstructing intra-site patterns in Neolithic lakeshore settlements: the state of archaeobotanical research and future prospects. Proceedings of the International Conference in Zurich: 69-94

Jeraj M, Velušček A, Jacomet S (2009) The diet of Eneolithic (Copper Age, Fourth millennium cal B.C.) pile dwellers and the early formation of the cultural landscape south of the Alps: a case study from Slovenia. Veg Hist Archaeobot 18:75-89

Jones G, Valamoti S, Charles M (2000) Early crop diversity: a "new" type glume wheat from northern Greece. Veg Hist Archaeobot 9(3):133-146

Jovanović B (1971) Metalurgija Eneolitskog Perioda Jugoslavije. Arheološki institute, Beograd

Jovanović B (2009) Beginning of the metal age in the Central Balkans according to the results of the archaeometallurgy. J Min Metall 45(2):143-148

Kalicz N (1970) Clay gods: the neolithic period and the Copper Age in Hungary. Hereditas, Budapest

Kapuran A, Milošević S (2013) Rockshelter Mokranjske stene-a new late prehistoric site in Eastern Serbia region. Archaeologia Bulgarica XVII(2):17-37

Kasper K (2003) Macrobotanical Analysis in Southeast Hungary: The Vésztõ- Bikeri Site. The Florida State University College of Arts and Sciences, Dissertation

Keeley HCM (1978) The cost-effectiveness of certain methods of recovering macroscopic organic remains from archaeological sites. J Archaeol Sci 5(2):179-183

Kenéz Á, Petö Á, Gyulai F (2014) Evidence of 'new glume wheat' from the Late Neolithic (Copper Age) of south-eastern
Hungary (4th millennium cal. B.C.). Veg Hist Archaeobot 23: $551-566$

Kohler-Schneider M (2003) Contents of a storage pit from Late Bronze Age Stillfried, Austria: another record of the "new" glume wheat. Veg Hist Archaeobot 12(2):105-111

Kreuz A, Schäfer E (2011) Weed finds as indicators for the cultivation regime of the early Neolithic Bandkeramik culture? Veg Hist Archaeobot 20(5):333-348

Krznarić Škrivanko M (2007) Vinkovci-Matije Gupca 14. In: Blanda M (ed) Hrvatski Arheološki Godišnjak. 4. Ministarstvo Kulture, Zagreb, pp. 81-84

Lister DL, Jones MK (2013) Is naked barley an eastern or a western crop? The combined evidence of archaeobotany and genetics. Veg Hist Archaeobot 22:439-446

Magyari E, Chapman J, Fairbairn AS, Francis M, de Guzman M (2012) Neolithic human impact on the landscapes of North-East Hungary inferred from pollen and settlement records. Veg Hist Archaeobot 21:279-302

Miculinić K, Mihaljević M (2003) Analiza faune prapovijesnog nalazišta Slavča - Nova Gradiška Opvsc. Archaeol 27:71-80

Mihaljević M (2004) Slavča. In: Mesić J (ed) Hrvatski Arheološki Godišnjak 1. Ministarstvo Kulture, Zagreb, pp. 39-40

Mihaljević M (2005) Slavča. In: Mesić J (ed) Hrvatski Arheološki Godišnjak 2. Ministarstvo Kulture, Zagreb, pp. 53-55

Mihaljević M (2006) Slavča. In: Mesić J (ed) Hrvatski Arheološki Godišnjak 3. Ministarstvo Kulture, Zagreb, pp. 75-76

Mihaljević M (2007) Slavča. In: Blanda M (ed) Hrvatski Arheološki Godišnjak 4. Ministarstvo Kulture, Zagreb, pp. 94-95

Mihaljević M (2008) Slavča. In: Mesić J (ed) Hrvatski Arheološki Godišnjak 5. Ministarstvo Kulture, Zagreb, pp. 126-127

Mihaljević M (2009) Slavča. In: Wiewegh Z (ed) Hrvatski Arheološki Godišnjak 6. Ministarstvo Kulture, Zagreb, pp. 88-89

Miloglav I (2007) Ervenica - dio naselja Vučedolske kulture. Opvscvla Archaeologica 31:27-48

Miloglav I (2012) Topografija nalazišta vučedolske kulture na vinkovačkom području. In: Petković D (ed) Acta Musei Cibalensis 5 Arheološki i povijesno- topografski radovi. Gradski muzej Vinkovci, Vinkovci, pp. 69-94

Mlekuž D (2007) Who were the Cyclopes? Odyssey and Neolithic, Eneolithic and Bronze Age pastoralists from the east Adriatic coast and Dinarides. Situla 46:1-14

Molnár S, Sümegi P (2007) A long history of the Kiri-tó meander. In: Whittle A (ed) The early neolithic on the great hungarian plain: investigations of the koros culture site of ecsegfalva 23. County Bekes. Akaprint, Budapest, pp. 47-65

Motuzaite-Matuzeviciute G, Staff RA, Hunt HV, Liu X, Jones MK (2013) The Early Chronology of Broomcorn Millet (Panicum Miliaceum) in Europe. Antiquity 87:1073-1085

Nagy-Bodor E, Jarai-Komlodi M, Medve A (2000) Late glacial and post glacial pollen records and inferred climatic changes from Lake Balaton and the Great Hungarian Plain. In: MB H (ed) Climate: Past, Present \& Future. Geological Society Special Publication 181, London, pp. 121-133

Obelić B, Horvatinćić N, Krajcar Bronić I (2002) Rudjer Boškovic Institute Radiocarbon Measurements XV. Radiocarbon 44(2):601630

Orton D (2012) Herding, settlement and chronology in the Balkan Neolithic. Eur J Archaeol 15(1):5-40

Parkinson WA (2006) The social organization of Early Copper Age tribes on the Great Hungarian Plain, BAR,International Series 1573. Archaeopress, Oxford

Parkinson WA, Yerkes R, Gyucha A (2004) The transition from the Neolithic to the Copper Age: excavations at Vésztő-Bikeri, Hungary, 2000-2002. J Field Archaeol 29(1/2):101-121

Pearsall D (2000) Paleoethnobotany: a handbook of procedures, 2nd edn. Academic Press, San Diego 
Prøsch-Danielsen L (1993) Prehistoric agriculture revealed by pollen analysis, plough-marks and sediment studies at Sola, southwestern Norway. Veg Hist Archaeobot 2(4):233-244

Raczky P, Siklósi Z (2013) Reconsideration of the Copper Age chronology of the eastern Carpathian Basin: a Bayesian approach. Antiquity 87(336):555-573

Radivojević M, Rehren T, Pernicka E, Šljivar D, Brauns M, Borić D (2010) On the origins of extractive metallurgy: new evidence from Europe. J Archaeol Sci 37:2775-2787

Radmanović D, Kostić D, Lujić J, Blažić S (2014) Vertebrate fauna at the Neolithic and Eneolithic Sites in Vojvodina (Serbia). J Nat Sci Matica Srpska Novi Sad 126:75-86

Reed K (2011) The plant remains. In: Balen J (ed) Đakovo-franjevac: late neolithic settlement, Musei archaeologici zagrabiensis catalogi et monographiae vol VII. Arheološki muzej u Zagrebu, Zagreb, pp. 126-127

Reed K (2013) Farmers in Transition: the archaeobotanical analysis of the Carpathian Basin from the Late Neolithic to the Late Bronze Age (5000-900 BC). Unpublished PhD thesis. School of Archaeology and Ancient History, University of Leicester

Reed K (2015) From the field to the hearth: plant remains from Neolithic Croatia (ca. 6000-4000 cal bc). Veg Hist Archaeobot 24(5):601-619

Rougemont $\mathrm{F}$ (2014) Sheep rearing, wool production and management in Mycenaean written documents. In: Breniquet $\mathrm{C}$, Michel C (eds) Wool economy in the ancient Near East and the Aegean: from the beginnings of sheep husbandry to institutional textile industry. Oxbow books, Oxford, pp. 340-370

Skelec G (1997) Prapovijesno nalazište Slavča. Opvscvla Archaeologica 21: $217-233$

Schmidl A, Jacomet S, Oeggl K (2007) Distribution patterns of cultivated plants in the Eastern Alps (Central Europe) during Iron Age. J Archaeol Sci 34:243-254

Šercelj A (1981-1982) Pomen botaničnih raziskav na koliščih Ljubljanskega barja. Poročilo o Raziskovanju Paleolita, Neolita in Eneolita v Sloveniji 9-10:101-106

Šercelj A, Culiberg M (1980) Paleobotanične raziskave kolišča na Partih (Izkopavanja 1978). Poročilo o Raziskovanju Paleolita, Neolita in Eneolita v Sloveniji 8:83-87

Šercelj A, Culiberg M (1984) Rastlinski ostanki iz Ajdovske jame pri Nemški vasi. Poročilo o Raziskovanju Paleolita, Neolita in Eneolita v Sloveniji 12:33-37

Sherratt A (1981) Plough and pastoralism: aspects of the secondary products revolution. In: Hodder I, Isaac G, Hammond N (eds) Pattern of the Past. Cambridge University Press, Cambridge, pp. 261-301

Sherratt A (1983) The secondary exploitation of animals in the old world. World Archaeol 15(1):90-104

Sherratt A (1998) The human geography of Europe: a prehistoric perspective. In: Butlin RA, Dodgshon RA (eds) An Historical Geography of Europe. Oxford University Press, Oxford, pp. 1-25

Sherratt A, Sherratt ES (1993) The growth of the Mediterranean economy in the early first millennium BC. World Archaeol 24(3):361-378

Šljivar D (2006) The earliest copper metallurgy in the Central Balkans. Assoc Metall Eng Serbia 12:93-104

Spangenberg JE, Jacomet S, Schibler J (2006) Chemical analyses of organic residues in archaeological pottery from Arbon Bleiche 3,
Switzerland-evidence for dairying in the late Neolithic. J Archaeol Sci 33(1):1-13

Sraka M (2014) Bayesian modeling the $14 \mathrm{C}$ calendar chronologies of the Neolithic-Eneolithic transition. Case studies from Slovenia and Croatia. In: Schier W, Drașovean F (eds) The Neolithic and Eneolithic in Southeast Europe: new approaches to dating and cultural synamics in the 6th to 4th millennium BC, Prähistorische Archäologie in Südosteuropa, vol 28. Verlag Marie Leidorf GmbH, Berlin, pp. 369-396

Stein GJ (1987) Regional economic integration in early state societies: third millennium B.C. pastoral production at Gritille, southeast Turkey. Paléorient 13(2):101-111

Tasić N (1979) Tiszapolgár i Bodrogkeresztúr kultúra. In: Tasić N (ed) Praistorija Jugoslavenskih Zemalja III. Eneolitsko doba, Sarajevo, pp. $55-85$

Tasić N (2003-2004) Historical picture of development of Bronze Age cultures in Vojvodina. СТАРИНАР 53-54:23-34

Tolar T, Jacomet S, Velušček A, Čufar K (2011) Plant economy at a late Neolithic lake dwelling site in Slovenia at the time of the Alpine Iceman. Veg Hist Archaeobot 20(3):207-222

Tóth P, Demján P, Griačová K (2011) Adaptation of settlement strategies to environmental conditions in southern Slovakia in the Neolithic and Eneolithic. Documenta Praehistorica 38:307321

Trbojević-Vukičević T, Marenjak TS, Kužir S, Čataj L (2011) Arheological and archaeozoological evidence of milk as a food in the territory of Croatia. Mljekarstvo 61(4):319-325

Tutin TG, Heywood VH, Burges NA, Moore DM, Valentine DH, Walters SM, Webb DA (1964-1980) Flora Europaea, vol 1-5. Cambridge University Press, Cambridge

Valamoti SM (2004) Plants and people in Late Neolithic and Early Bronze Age Northern Greece, BAR International Series 1258. Archeopress, Oxford

Valamoti SM (2013) Millet, the late comer: on the tracks of Panicum miliaceum in prehistoric Greece. Archaeol Anthropol Sci. doi:10. 1007/s12520-013-0152-5

Van der Veen M (1992) Crop husbandry regimes: an archaeobotanical study of farming in northern England 1000 BC - AD 500. J.R. Collis Publications, Sheffield

Van der Veen M (2007) Formation processes of desiccated and carbonized plant remains - the identification of routine practice. J Archaeol Sci 34(6):968-990

Van der Veen M, Fieller N (1982) Sampling seeds. J Archaeol Sci 9(3): 287-298

Van Zeist W (2003) Plant husbandry and vegetation of tell Gomolava, Vojvodina, Yugoslavia. Palaeohistoria 43(44):87-115

Velušček A, Čufar K, Culiberg M, Toškan B, Dirjec J, Malez V, Janžekovič F, Govedič M (2004) Črešnja pri Bistri, a newly discovered pile-dwelling settlement in the Ljubljansko barje. Arheološki Vestnik 55:39-54

Zohary D, Hopf M, Weiss E (2012) Domestication of plants in the old world: the origin and spread of domesticated plants in south-west Asia, Europe, and the Mediterranean Basin. Oxford University Press, Oxford 